\section{Unscientific Art (?)}

IN NATURE, vol. xix. p. 460, Mr. Luck complains of the crawing in the Graphic for December 28 , wherein the observer is represented as "sloping the barometer at an angle of about $30^{\circ}$ from the vertica!," in order to talie a reading on a marine barometer by means of the lanterin for better illumination. May not the artist be correct, and Mr. Buck have discovered a mare's nest? The barometer may be placed entirely horizontal for reading the scale, after the vernier has once been set when the instrument was vertical.

Grosvenor Road, Highbury New Park, N., March 2I

\section{OUR ASTRONOMICAL COLUMN}

The Distant Herschelian Companion of $\gamma$ LeONis. -In 1861 Prof. Winnecke, writing from Pulkowa, drew attention to a star of the ninth magnitude near the doublestar $\ddot{\gamma}$ Leonis, which M. Otto Struve had found to have an annual proper motion exceeding $0^{\prime \prime} \cdot 5$. The star was observed with the Dorpat transit-instrument, on April 12, 1820 , and once by Bessel in zone 502, on April 12, I831, and from these observations compared with two at Pulkowa in April, I86 $\mathrm{I}$, and with micrometrical measures from $\gamma$ Leonis by M. Otto Struve, Prof. Winnecke concluded that the proper motion of the small star with respect to the neighbouring binary, was very nearly $o^{\prime \prime} \cdot 85$ in R.A. and $o^{\prime \prime} \cdot$ Io in declination, annually. Sir W. Herschel observed a distant companion of $\gamma$ Leonis, the mean of two angles giving $297^{\circ} \cdot 5$ for about $1782^{\circ} 9$, with a distance of III" 4 , which he thought was "pretty accurate," though as we are now aware, many of these wider measures of Sir W. Herschel require material correction.

We refer to this star from having remarked that $M$. Flammarion, in his recently published "Étoiles Doubles et Multiples en Mouvement relatif certain," has made it the subject of a strangely confused article, which is calculated to mislead the reader who cannot refer to original authorities. The star had been measured by Secchi in 1856, and by Powell in $186 \mathrm{I}$, and M. Flammarion states that "the enormous difference between the measure of 1782 and that of 1856 " had induced him to search for other observations and to reobserve it himself, which he did, in 1877 . He says he had found five observations by Flamsteed in 1691 , ten by $T$. Mayer in 1755 , and fifteen by C. Mayer in 1777 ; these, it is added, are not very precise, for they consist only of differences of right ascension, without taking account of the declination; nevertheless he considered they had their value, and comparing his own measures of 1877 with previous observations separately, he deduces "a very surprising result," viz., that the distant star is remarkable for its motion, which, if one may judge by the totality of observations, has a mean value of $\mathbf{I}^{\prime \prime} \cdot 08$, but which appears variable, as "at present it certainly has not that value."

The main cause of M. Flammarion's difficulty is his having confounded two quite distinct objects: we have not referred to the work of $C$. Mayer, but the star observed by Flamsteed, which he more than once calls "Comes $\gamma$," and that observed by Tobias Mayer, is really the bright neighbour of $\gamma$, or 40 Leonis ; Flamsteed did observe the declination, as will be seen in his column "Distantiæ a vertice correctæ;" and Mayer also noted the declination on one occasion, though generally recording only the right ascension. M. Flammarion says he found fire observations of Flamsteed in $169 \mathrm{I}$, which is a greater number than we recognise in the "Historia Cœlestis," but there are observations in 1690 and 1692 . The zenith distances of $\gamma$ Leonis and Comes on April 6, I69I, and the names of the stars on January 23, 1692 , are interchanged in the "Historia Cœlestis." Tobias Mayer's observations do not apply to the year 1755, when his observatory at Göttingen was not yet erected, but to 1756 and 1757 , chiefly the former year.
Bessel's observation applies to $183 \mathrm{I}$, not 1825 , as $M$. Flammarion assumes.

The star in question is No. 90, in Argelander's valuable treatise, "Untersuchungen über die Eigenbewegungen von 250 Sternen, \&c.," where he deduces for the annual proper motion in arc of great circle, $\mathrm{O}^{\prime \prime} .512$ in the direction $270^{\circ}$, or the proper motion is entirely in R.A. He observed the star upon the meridian at Bonn, once in 1857 and four times in $1862-63$. It was also meridionally observed at Greenwich in 1862. It is No. 234, Hour X., in Weisse's Bessel. Thus we have three stars situate within half a degree, with large proper motions, very divergent, however, in direction :-

$$
\text { Secular P.M. Direction. }
$$

Authority.

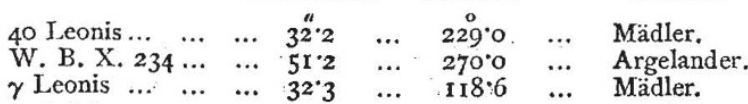

A METEOR WTTH SHORT PERIOD OF Revolution.In the very interesting report of the "Luminous Meteor Committee" of the British Association for 1877-78, we find a note by Capt. G. L. Tupman, referring to a fireball seen on November 27,1877 , which he considers to have been moving in a nearly circular orbit, with short periodic time. Capt. Tupman observed this meteor from a position about half a mile east of the Royal Observatory, Greenwich ; it began as a first or second magnitude star, but suddenly increased in brilliancy and size to a: fine bluish white fire-ball ten or twelve minutes in diameter, emitting a train, coloured blue, red, and green, many degrees long. It moved very slowly, so slowly, indeed, towards the end of its course, that it appeared to come almost to a standstill. The duration was considered to be fifteen or sixteen seconds. The meteor was observed by Mr. H. Corder, at Writtle, near Chelmsford, and by Mrs. Ware, at Clifton Down, Bristol, and the positions for beginning and ending, estimated at these stations, were found to be in remarkable agreement, the true path deduced from these satisfying them all, both azimuths and altitudes, within $\mathrm{I}^{\circ}$.

It appears that the meteor first became visible at a real height of fifty-six miles vertically over a point off the mouth of the Thames in long. $\mathrm{I}^{\circ} 2 \mathrm{I}^{\prime}$ E., lat. $5 \mathrm{I}^{\circ} 33^{\prime}$, and disappeared when it had descended to a height of thirteen miles vertically over a point, about twelve miles west of St. Omer, in France, in long. $2^{\circ} \mathrm{o}^{\prime}$ E., lat. $50^{\circ} 45^{\prime}$, the length of the entire path being about eighty miles.

Capt. Tupman thinks the radiant point was pretty accurately determined in R.A. $285^{\circ}$, Decl. $+64^{\circ}$, or in longitude $340^{\circ}$, and latitude $+83^{\circ}$. The elements of the real orbit, which, with the aid of the other corresponding data depending upon the earth's position in her orbit, are thence deduced, are as follows, taking the real duration at fifteen seconds:-

$\begin{array}{llllllll}\text { Peribelion distance } & \ldots & \ldots & 0.9858 & \text { Excentricity } & \ldots & 0.1568\end{array}$

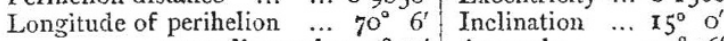

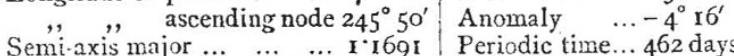
Motion-direct.

The precise Greenwich time of the occurrence of the meteor was roh. $26 \mathrm{~m}$.

If the duration of visibility is diminished to $7 \frac{1}{3}$ seconds the elements are still very similar to the above; the semiaxis major becomes $1 \cdot 3785$ and the period 59I days. Capt. Tupman remarking that such favourable conditions for inferring the orbit of a meteor may rarely happen, adds, it is sufficient for the establishment of a short periodic time (such as 500 days) that "the meteor moved slowly from a fairly well-determined radiant distant about $90^{\circ}$ from the point of the heavens towards which the earth's motion was directed."

We may mention that there is one singular circumstance not alluded to in Capt. Tupman's note: the elements defining the position of the orbit of the meteor 
have a striking general resemblance to those of the orbit of Biela's comet, in the descending node of which body the earth was precisely situated at the time.

\section{FOSSIL CALCAREOUS ALGAE}

$\mathrm{T}$

IE very important memoir of $M$. Munier-Chalmas, "Sur les Algues calcaires appartenant au groupe des Dasycladées Harv. et confondues avec les Foraminiferes," which was published in the Comptes Rendus Hebdomadaires of the French Academy of Science for October 29,1877 , opens up quite a new or almost a new field of research, which has been followed up by the same author in a note presented last month to the Geological Society of France, "On the genus Ovulites." Though regarded by some of the most eminent palæontologists as a monothalmic foraminifer related to Lagena, the genus Ovulites is herein clearly demonstrated to be neither more nor less than an articulation of a siphonaceous alga having very close affinities to Penicellus.

Ovitlites margantula is described by Messrs. Parker and Jones "as a common Foraminifer of the 'Calcaire grossier.' Shaped like an egg, and when full grown about the size of a mustard-seed, it is one of the most elegant of the fossil forms. The large terminal apertures, moreover, curiously impress upon the mind its resemblance to a 'blown' bird's egg. [Written in I 860; nowadays bird's eggs are not thus blown.] It is the largest of the monothalamous Foraminifera. As a species it appears to have been short-lived. Fully developed in the deposits of Hauteville and Grignon it breaks in at once in the Eocene period. It lingers as an attenuated form in the Miocene beds of San Domingo. A recent Ovulite has not been met with. Scarcely another Foraminifer presents us with a similarly brief history-an undescribed form allied to Dactylopora affording almost the only parallel (namely, Acicularia pavantina, d'Arch.)."

In passing it may be noted that without doubt this lastmentioned form is also only a portion of a calcareous alga.

The earlier memoir, of which the Comptes Rendus publishes only an abstract, reminds us that it is not so very long ago ( 1842 ) since Prof. Decaisne demonstrated that a number of marine forms known as zoophytes, Corallina, Cymopolia, Neomeris, Penicellus, Udotea, Halimeda, \&c., were in reality veritable algæ. But we may remark that Prof. Schweigger, of Königsberg, had, from actual observation of living specimens of several species of these calcareous algæ at Villefranche, come to the same conclusion in 1818 ("Beobachtungen auf naturhistorischen Reisen. Anat.-phys. Untersuchungen über Corallen," Berlin, 1818). To go back to the pre-Linnean times, Ray ( 1690 ) described Corallina as "plantæ genus in aquis nascens," and Spallanzani, Carolini, and Olivi even maintained the same against the peculiar reasonings of Ellis, the authority of Linneus, and clespite the conversion of Pallas; but so influenced by authority were, apparently, the botanists down to 1842 , that a Professor of Botany in the Edinburgh University (Graham) once politely requested the zoologists to keep their cryptogamia to themselves, and a Professor of Botany in the Dublin University (Harvey), in the first edition of his "Manual of British Algæ" (184I), did not include any of the Corailines. Since the memoirs of Decaisne and Chauvin, all this has changed, and we imagine that there is now no difference of opinion existing among botanists as to the general affinities of the living forms of calcareous algæ.

M. Munier-Chalmas in his memoir demonstrates that there must be also added to this group a numerous series of fossil forms which the old authors placed among the polyps, and which most of the modern writers on the subject have ranked among the foraminifera. Bosc in I 806 described and figured (Journal de Physique, Juin I 806$)$ some fossil organised bodies under the name of
Rétéporites ovoides, for which bodies Lamarck in 1816 established the genus Dactylopora. "The most singular varieties of opinion have existed," writes Dr. Carpenter in his well-known "Introduction to the Study of the Foraminifera," "as to the true character of these fossil organisms. In separating them generally from Retepora Lamarck still associated them in the same group of sup. posed zoophytes; this position was also accepted for the genus by De Blainville and Defranc." [It is but justice to De Blainville to point out that he quotes without disapproval the statement of Schweigger, "que les dactylspores et les ovulites ne sont rien autre chose que des articulations d'une grande espèce de cellaire, analogue à la cellaire salicorne"]. "In 1852 Dactylopora was included among the Foraminifera by D'Orbigny, who showed, notwithstanding, by the place he assigned to it, a misapprehension of the real nature scarcely less complete than that under which his predecessors had lain; for he ranks it in his order Monostegues, next to the unilocular Ovulites, and says of it: 'C'est une Ovulite également percée des deux bouts, pourvue des larges pores placés par lignes transverses.' How utterly erroneous is this description will appear from the details to be presently given, yet D' Orbigny's authority has given it currency enough to cause it to be accepted by such intelligent palæontologists as Pictet and Bronn, who in the latest editions of their respective treatises have transferred Dactylopora to the place indicated by him, not, however, without the expression of a doubt on the part of Bronn as to whether the true place of the genus is not among the Fistulidæ in alliance with Synapta and Holothuria - a suggestion that indicates a perversion of ideas on the subject for which it is not easy to account. The complex structure of the organism in question was first described and the interpretation of that structure on the basis of an extended comparison with simpler forms was first given, by Messrs. Parker and Jones in so unobtrusive a manner as scarcely to challenge the attention which their investigations deserve, and I gladly avail myself of the opportunity which the present publication affords to give a fuller account, with the requisite illustrations of this remarkable type, the elucidation of which seems to me not unlikely to lead to a reconsideration of the place assigned to many other organisms at present ranked among Zoophytes or Polyzoa;" and then follow nine pages of a most elaborate description of every ridge and furrow, of every elevation and depression to be met with in any of the so-called species, so that probably no single vegetable cell was ever before so minutely described.

The genus is placed the eleventh in order of the family Miliolida, a family which contains some of the most typical of Foraminifers. "It may be conjectured without much improbability," writes Dr. Carpenter, "that Dactylopora is only the single representative of a group whose various forms filled up the hiatus which at present intervenes between itself and its nearest allies among the ordinary Foraminifera." But, writes M. Munier-Chalmas, "the study and comparison of species of Dasycladus, Cymopolia, Acetabularia, Neomeris, \&c., in the herbarium of the museum, and in that of M. Ed. Bornet, who placed without reserve at my disposal his library and collections of these plants, proved to me that the species of Dactylopora, Acicularia, Polytrypa, \&c., are decidedly Algæ, very nearly allied to species of the recent genera just quoted, if not identical therewith. The accompanying figures show plainly, for example, that the genera Cymopolia and Polytrypa may be united; for the typical species thereof offer in every respect the same generic characters, and there is even a difficulty to find for them sufficiently distinct specific characters. Under the denomination of 'Siphonee verticillate' I unite (I) Those green-spore bearing algæ arranged by Harvey in the family of the Dasycladeæ; (2) All those fossil gener related to Larvaria, Clypeina, Polytrypa, Acicularia, Dac- 